\title{
New markers of atherosclerosis: a threshold level of heteroplasmy in mtDNA mutations
}

\author{
Margarita A. Sazonova ${ }^{1,2}$, Anastasia I. Ryzhkova ${ }^{2}$, Vasily V. Sinyov ${ }^{1}$, Elena V. Galitsyna ${ }^{2}$, Varvara A. Orekhova ${ }^{2,3}$, \\ Alexandra A. Melnichenko², Alexander N. Orekhov ${ }^{2,3}$, Alessio L. Ravani ${ }^{4}$, Igor A. Sobenin ${ }^{1,2}$
}

\author{
${ }^{1}$ Laboratory of Medical Genetics, Russian Cardiology Research and Production Complex, 121552 Moscow, Russia. \\ ${ }^{2}$ Laboratory of Angiopathology, Institute of General Pathology and Pathophysiology, 125315 Moscow, Russia. \\ ${ }_{3}^{3}$ Institute for Atherosclerosis Research, Skolkovo Innovative Centre, 121609 Moscow, Russia. \\ ${ }^{4}$ Unit for the Study of Morphology and Arterial Function, Centro Cardiologico Monzino, IRCCS, 20138 Milan, Italy.
}

Correspondence to: Dr. Alessio L. Ravani, Unit for the Study of Morphology and Arterial Function, Centro Cardiologico Monzino, IRCCS, Via C. Parea, 4, 20138 Milan, Italy. E-mail: alessio.ravani@ccfm.it

How to cite this article: Sazonova MA, Ryzhkova AI, Sinyov VV, Galitsyna EV, Orekhova VA, Melnichenko AA, Orekhov AN, Ravani AL, Sobenin IA. New markers of atherosclerosis: a threshold level of heteroplasmy in mtDNA mutations. Vessel Plus 2017;1:182-91.

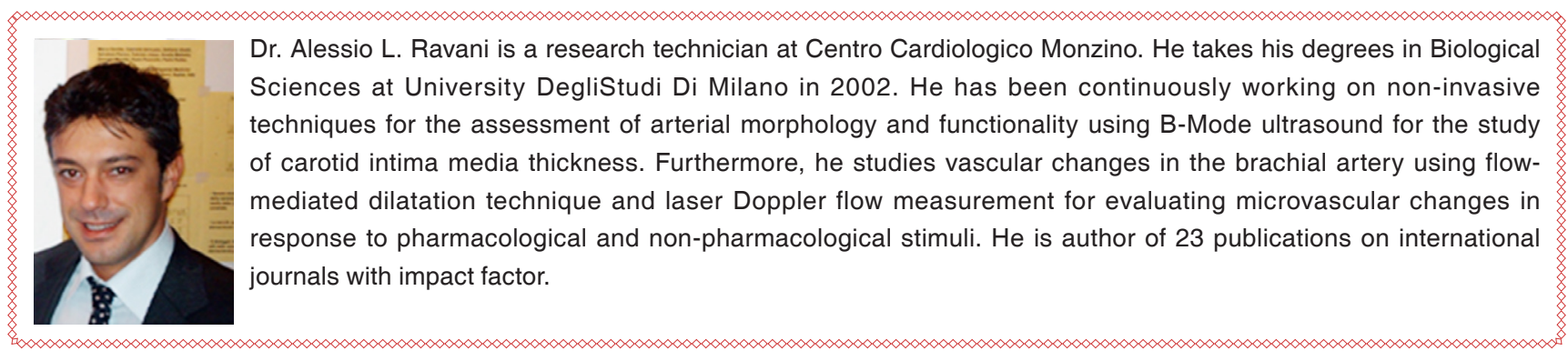

Article history:

Received: 26 May 2017

Accepted: 11 Sep 2017

Published: 28 Dec 2017

Key words:

Threshold heteroplasmy level,

mutation,

mitochondrial genome,

mitochondrial DNA,

atherosclerosis,

gene,

marker

\begin{abstract}
Aim: The aim of the present article was the detection of threshold heteroplasmy level of mitochondrial DNA mutations, above which a patient is at increased risk of atherosclerotic lesions. Besides, this parameter was detected for mutations, in which after reaching threshold heteroplasmy level, a protective antiatherogenic effect started to appear. Methods: The participants of the study were 700 women and men from the Moscow region. Fragments of DNA, amplified by polymerase chain reaction, were analyzed with pyrosequencing technology. Then on the basis of pyrograms' peaks in the samples, the heteroplasmy level of the investigated mitochondrial genome mutations was detected. Results: The threshold heteroplasmy level of 11 investigated mutations (m.5178C $>$ A, m.15059G $>$ A, m.652delG, m.13513G $>$ A, m.14846G $>$ A, m.652insG, m.12315G $>$ A, m.3336T $>$ C, m.1555A $>$ G, m.14459G $>$ A, m.3256C $>$ T) in individuals with atherosclerotic plaques or thickening of the intima-medial layer of carotid arteries was detected. Conclusion: Using the method developed in our laboratory, the authors managed to determine threshold heteroplasmy levels of 11 mitochondrial genome mutations associated
\end{abstract}

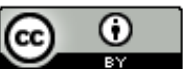

This is an open access article licensed under the terms of Creative Commons Attribution 4.0 International License (https://creativecommons.org/licenses/by/4.0/), which permits unrestricted use, distribution, and reproduction in any medium, as long as the original author is credited and the new creations are licensed under the identical terms.

For reprints contact: service@oaepublish.com

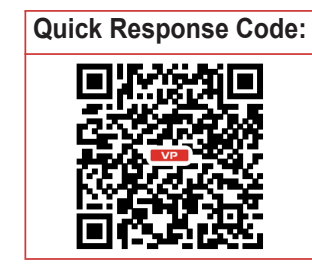


with atherosclerosis. The authors suggest that threshold heteroplasmy levels of these mutations is a new criterion for evaluation of predisposition to the occurrence and development of atherosclerotic lesions in human arteries.

\section{INTRODUCTION}

Atherosclerosis of human major vessels is often a morphological basis of mortality from cardiovascular diseases. In this pathology intima of arteries is damaged, luminal occlusion occurs and blood supply to organs deteriorates ${ }^{[1-5]}$. Atherosclerosis is difficult to recognize in the early stages. Molecular genetic markers could help the diagnostics of this disease. Unfortunately, compared to traditional single risk factors of atherosclerosis, nuclear genome mutations have rather low diagnostic and prognostic significance. The relative risk of one such mutation is 1.06-1.40. The total risk of cardiovascular diseases caused due to all known mutations in the nuclear genome is approximately $5 \%^{[6-10]}$.

According to the literature, a variety of diseases is associated with some mutations in mitochondrial DNA (mtDNA). These mutations often correlate with pathologies which often occur together with atherosclerosis ${ }^{[11-15]}$. The penetrance of mtDNA mutations depends on the percentage of normal and mutant copies of genome, i.e. the heteroplasmy level of mitochondrial mutations. That is why, during the analysis of the linkage of mitochondrial genome mutations with human diseases, the value of heteroplasmy level above which in a person begins the occurrence and development of pathologies or begins to show a protective effect caused by mutations is determined. The information about the threshold heteroplasmy level of mitochondrial genome mutations associated with certain diseases, can help in assessing the predisposition and the early diagnosis of these pathologies.

In preliminary studies, a total of 11 of $42 \mathrm{mtDNA}$ mutations associated with different pathologies was found to have an association with atherosclerosis ${ }^{[16-19]}$. In view of these facts, the aim of the present article was the detection of threshold heteroplasmy level of mtDNA mutations, above which atherosclerotic lesions were found in patients. Besides, this parameter was detected for mutations, in which after reaching the threshold heteroplasmy level started to appear a protective antiatherogenic effect.

The estimation of the mutations' threshold heteroplasmy level was carried out in the following samples of the study participants: (1) with atherosclerotic plaques; (2) with an increased intima-medial thickness of carotid arteries (IMT CA); (3) with a normal carotid intima.

It should be emphasized that at the present time there are no published studies which have investigated the threshold heteroplasmy level of mitochondrial genome mutations in atherosclerosis. Therefore, this article, dedicated to the identification of this parameter in patients with atherosclerotic lesions in blood vessels' wall, is quite relevant, well-timed and novel.

\section{METHODS}

\section{Inclusion criteria}

The present research was carried out according to the Helsinki Declaration of 1975 as revised in 1983. It was endorsed by the local ethics committees of the Institute for Atherosclerosis Skolkovo Innovation Center, Moscow, Russia and Research Institute of General Pathology and Pathophysiology, Moscow. Prior to their inclusion in the study, all the study participants gave an informed consent in written form.

The participants in the study were enrolled consecutively from the number of patients at Moscow municipal outpatient clinics No. 202, who were examined for cardiovascular risk factors (mainly arterial blood pressure and blood cholesterol). The investigated sample included 700 study participants. The age of men was over 40 -year-old, and the age of women was over $50^{[20,21]}$. The average age of the participants in the sample was 62.3 years $(S D=8.7)$, the ratio of men and women was $362: 338(51.7 \% / 48.3 \%)$. As a result of ascertaining the clinical diagnosis of atherosclerosis, the sample was divided into 2 groups: (1) conventionally healthy participants without ultrasonographic signs of atherosclerosis (339 people, or $48.4 \%$ of the sample); (2) patients without clinical manifestations of atherosclerosis who have ultrasonographic signs of preclinical atherosclerosis: the presence of lesions in the carotid artery lumen (more than $10 \%$ of the artery lumen) (361 people, or $51.6 \%$ of the sample).

The criteria for exclusion were: anatomical organization of the neck and carotid arteries which prevented qualitative ultrasonography, serious life-threatening diseases and the refusal to sign an informed consent to the investigation. Individuals with a history of, or a diagnoses of the following diseases were excluded from the study: breast cancer or nodal form of mastopathy; stroke or coronary heart disease; liver dysfunction; chronic kidney disease; type 2 diabetes; obesity (body 
mass index $>30 \mathrm{~kg} / \mathrm{m}^{2}$ ); untreated high blood pressure; cigarette smoking; pulmonary embolism or deep vein thrombosis ${ }^{[2,21]}$.

The presence of increased IMT CA or atherosclerotic plaques was detected by high-resolution B-mode ultrasound using a SSI-1000 scanner (SonoScape, China) equipped with a $7.5-\mathrm{MHz}$ linear array probe. Carotid ultrasonography was performed by the same researcher throughout the study. The far walls of the right and left common carotid arteries, the bifurcation, the internal and the external carotid arteries were visualized. The c-IMT of the first centimeter of the common carotid artery was measured in three different projections (anterior, posterior and lateral), and analyses carried out with the use of dedicated software M'Ath (Metris, SRL France). The average value of these measures was considered as an integral indicator of intima-medial thickness ${ }^{[22-25]}$. The measurements were carried out in accordance with the Mannheim criteria and the criteria of the investigation Improve ${ }^{[26,27]}$.

\section{Materials}

The materials for the study were blood leukocyte samples of participants. Blood for genetic analysis was taken after an overnight fast in the amount of $9 \mathrm{~mL}$ from the ulnar vein in a $10 \mathrm{~mL}$ plastic tube containing sodium salt of $\mathrm{Na}_{2}$-ethylenediaminetetraacetic (EDTA) acid as an anticoagulant. A mother liquor of $0.1 \mathrm{~mol} / \mathrm{L}$ Na-EDTA in water ( $\mathrm{pH}$ 8.0) was used, to which fresh blood was added in a ratio of 9:1 to obtain a final $\mathrm{Na}$ EDTA concentration of $10 \mathrm{mmol} / \mathrm{L}$. Samples were stored at $-20^{\circ} \mathrm{C}$.

\section{Procedure}

It is noteworthy that in previous research from our laboratory, we haven't found any significant differences in heteroplasmy levels of the investigated mutations between leukocytes and platelets (blood cells having mitochondrial genome), so DNA samples for this study were isolated from whole blood ${ }^{[16-19,28]}$. This method was developed in our laboratory on the basis of technology of Maniatis ${ }^{[29]}$. For DNA isolation we used a lysis buffer $(0.32 \mathrm{~mol} / \mathrm{L}$ sucrose; $5 \mathrm{mmol} / \mathrm{L} \mathrm{MgCl}$; $100 \%$ Triton X-100; $0.01 \mathrm{~mol} / \mathrm{L}$ Tris- $\mathrm{HCl}, \mathrm{pH} 7.6$ ), and then deproteinization buffer ( $25 \mathrm{mmol} / \mathrm{L}$ EDTA pH 8.0; $75 \mathrm{mmol} / \mathrm{L} \mathrm{NaCl})$ and proteinase $\mathrm{K}$ solution $(20 \mathrm{mg} / \mathrm{mL}$ DNA purification from admixtures was carried out using phenol and chloroform. Precipitation of DNA was carried out using isopropanol, followed by washing in ethanol. The DNA precipitate was dissolved in $300 \mu \mathrm{L}$ of TE buffer $(10 \mathrm{mmol} / \mathrm{L}$ Tris- $\mathrm{HCl}, \mathrm{pH} 8.0,1 \mathrm{mmol} / \mathrm{L}$ EDTA). The DNA concentration in the obtained sample was identified by nanospectrophotometer IMPLEN NanoPhotometer ${ }^{\mathrm{TM}}$. After measuring the concentration, the DNA samples were stored at $-20^{\circ} \mathrm{C}$. For operating with a collection of DNA samples, the samples were diluted in TE buffer to a concentration of $0.03 \mu \mathrm{g} / \mu \mathrm{L}$.

The concentration of DNA solution in $n g / \mu L$ was measured using IMPLEN NanoPhotometer ${ }^{\top \mathrm{M}}$ nanospectrophotometer with the use of a LabelGuard ${ }^{\mathrm{TM}}$ microtubule in "DS DNA" mode at a wavelength of $260 \mathrm{~nm}^{[16,17]}$.

The DNA samples of the study participants were used for carrying out the polymerase chain reaction (PCR) of fragments containing the region of 11 investigated mutations $^{[11-15]}$.

Electrophoresis of isolated DNA samples and PCRfragments was carried out in a horizontal apparatus of Helicon company in agarose gel using $0.5 \times$ tris-borateEDTA (TBE) buffer. The concentration of agarose ("Fluka") was $0.8 \%$ (for DNA samples) and $1.5-2.0 \%$ (for PCR-fragments). The gel was stained by the addition of an ethidium bromide solution $(0.5 \mu \mathrm{g} / \mathrm{mL})$. As a colorant, a solution of bromophenol blue $(1 \mu \mathrm{L}$ for $10 \mu \mathrm{L}$ of sample) was used ${ }^{[16-18]}$. The composition of $10 \times \mathrm{TBE}$ : TrisHCl (108 g), boric acid (55 g), 0.5 mol/L EDTA, pH 8.0 (40 mL per 1 liter of buffer).

For the evaluation of molecular weight of the investigated PCR fragments, DNA markers of $1 \mathrm{~Kb}$ (13 fragments from 0.25 to $10 \mathrm{~Kb}$ ) and $100 \mathrm{bp}(10$ fragments from 100 to $1,000 \mathrm{bp}$ ) were used ${ }^{[16-18]}$.

For conducting PCR, DNA with a concentration of $0.1 \mu \mathrm{g} / \mathrm{mL}$ diluted with $\mu \mathrm{Q}$ and primers at a concentration of $10 \mathrm{pmol} / \mu \mathrm{L}$ were taken ${ }^{[16-18]}$. The reaction mixture and PCR conditions were the following: $\mu Q\left(\mathrm{H}_{2} \mathrm{O}\right): 4.6 \mu \mathrm{L}$; a mixture of dNTPs 10x: $2 \mathrm{mmol} / \mathrm{L}$ deoxyadenosine triphosphate, $2 \mathrm{mmol} / \mathrm{L}$ dTTP, $2 \mathrm{mmol} / \mathrm{L}$ dGTP, $2 \mathrm{mmol} / \mathrm{L}$

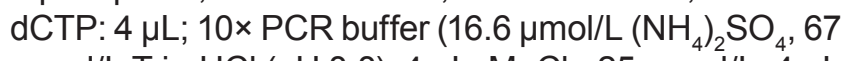
$\mathrm{mmol} / \mathrm{L}$ Tris- $\mathrm{HCl}$ (pH 8.8): $4 \mu \mathrm{L} ; \mathrm{MgCl}_{2}: 25 \mathrm{mmol} / \mathrm{L}: 4 \mu \mathrm{L}$ (at the required concentration of $2.5 \mathrm{mmol} / \mathrm{L}$ ); $2.4 \mu \mathrm{L}$ (at the required concentration of $1.5 \mathrm{mmol} / \mathrm{L}$ ); Taq polymerase: $1.33 \mu \mathrm{L}$; Matrix DNA: $4 \mu \mathrm{L}$; Primer F (+): $2.7 \mu \mathrm{L}$; Primer $\mathrm{R}(-): 2.7 \mu \mathrm{L}$. The reaction was carried out in $40 \mu \mathrm{L}$ of the reaction mixture ${ }^{[16,17]}$.

One of the PCR primers was biotinylated with the aim of the subsequent pyrosequencing of the PCR fragment. The study was carried out using amplifier "PTC DNA Engine 200". After that pyrosequencing of PCR fragments was conducted using the apparatus (PSQ96MA $)^{[30-34]}$. The pyrosequencing reaction included 4 stages $^{[30-34]}$.

Stage 1: the sequence primer was hybridized to a 
single-stranded PCR amplicon, which is used as a template. The obtained fragment was incubated with the following enzymes: DNA polymerase, ATPsulfurylase, luciferase and apyrase; and it was also incubated with the substrate: adenosine-5phosphosulfate and luciferin.

Stage 2: the first nucleotide was added to the reaction mixture. DNA polymerase completes it to the DNA strand, in accordance with the principle of complementarity. In this case, the reaction is accompanied by the release of pyrophosphate (PPi) in an amount equimolar to the sum of the included nucleotides.

Stage 3: ATP-sulphurylase converts PPi to ATP in the presence of adenosine-5-phosphosulfate. In this case, luciferin is converted into oxyluciferin, which generates visible light in proportion to the amount of ATP. A pyrosequenator detects this light and converts it into the corresponding peak on the pyrogram. The height of each peak is proportional to the intensity of the flash of light, and, consequently, to the number of analyzed nucleotides in the DNA strand. For example, if there is one nucleotide $C$ in a particular position of the DNA strand, a peak corresponding to a single flash will be seen on the pyrogram, and if there are three nucleotides $C$ in succession, a triple flash will be seen (i.e. the peak will be three times higher).

Stage 4: apyrase, a nucleotide-destroying enzyme, constantly removes the remaining nucleotides which were not attached and ATP. Afterwards another nucleotide is added to the reaction mixture.

To carry out the above-described investigation, it was necessary to conduct sample preparation: a mixture of primers for the sequence should be added to the studied single-chain biotinylated PCR-fragments. Streptavidin-sepharose particles were attached to these biotinylated PCR-fragments, which makes it possible to operate with single-strand PCR-fragments using streptavidin interacting with biotin.

Thealgorithm of sample preparation for pyrosequencing was as follows: (1) $2 \times$ Binding buffer [per $100 \mathrm{~mL}$ of the solution: $\mathrm{C}_{4} \mathrm{H}_{11} \mathrm{NO}_{3}(0.121 \mathrm{~g}), \mathrm{NaCl}(11.7 \mathrm{~g})$, EDTA $(0.0292 \mathrm{~g})$, Tween $20(100 \mu \mathrm{L})$. PH was adjusted to 7.6, $1 \mathrm{~mol} / \mathrm{L} \mathrm{HCl}$; (2) $1 \times$ Annealing buffer [per $100 \mathrm{~mL}$ of the solution: $\mathrm{C}_{4} \mathrm{H}_{11} \mathrm{NO}_{3}(0.242 \mathrm{~g}), \mathrm{C}_{4} \mathrm{H}_{6} \mathrm{MgO}_{4} \times 4 \mathrm{H}_{2} \mathrm{O}(0.043 \mathrm{~g})$. $\mathrm{PH}$ was adjusted to $7.6,4 \mathrm{~mol} / \mathrm{L} \mathrm{CH}_{3} \mathrm{COOH}$; (3) washing buffer [per $100 \mathrm{~mL}$ of solution: $\mathrm{C}_{4} \mathrm{H}_{11} \mathrm{NO}_{3}(0.121 \mathrm{~g})$. $\mathrm{PH}$ was adjusted to $7.6,4 \mathrm{~mol} / \mathrm{L} \mathrm{CH}_{3} \mathrm{COOH}$; and (4) $0.2 \mathrm{~mol} / \mathrm{L}$ $\mathrm{NaOH}$ (per $100 \mathrm{~mL}$ solution: $\mathrm{NaCl} 0.8 \mathrm{~g}$ ).
Then, a solution of streptavidin-sepharose was prepared for 1 sample: $40 \mu \mathrm{L} 2 \times \mathrm{BB}, 3 \mu \mathrm{L}$ of streptavidinsepharose particles, $7 \mu \mathrm{L}$ of $\mu \mathrm{Q} \mathrm{H}_{2} \mathrm{O}$. After that, the mode in the computer program for pyrosequencing was set. Into each test tube, $50 \mu \mathrm{L}$ of streptavidin-sepharose solution were added, previously shaking it with vortex. Samples were put in a shaker for $5 \mathrm{~min}$. At this time, $39 \mu \mathrm{L}$ of $1 \times \mathrm{AB}$ and $3 \mu \mathrm{L}$ of corresponding probe primer with a concentration of 2 optical units were added to each well of the pyrosequencing dish and the prepared pyrosequencing dish was placed in the runners of a vacuum sample preparation station. The dishes were placed into the appropriate sample niches in the sample preparation station, the following reagents were poured into all the baths: washing buffer (WB), $0.2 \mathrm{~mol} / \mathrm{L} \mathrm{NaOH}$, rectified alcohol $70 \%, \mu Q \mathrm{H}_{2} \mathrm{O}$. The nozzle with filters was placed into the dish with $\mu \mathrm{Q} \mathrm{H}_{2} \mathrm{O}$ and vacuum was switched on at the sample preparation station. In $20 \mathrm{~s}$ the nozzle was removed from the dish and dried in an upright position for $10 \mathrm{~s}$. Then the nozzle with filters was placed in the 96-well pyrosequencing plate with samples for $30 \mathrm{~s}$. Then the filters with samples were lowered into reagent dishes: rectified alcohol $70 \%$ (for $5 \mathrm{~s}$ ), then into $0.2 \mathrm{~mol} / \mathrm{L} \mathrm{NaOH}$ (for $5 \mathrm{~s}$ ), then into WB (for $10 \mathrm{~s}$ ) and then into $\mu \mathrm{Q} \mathrm{H}_{2} \mathrm{O}$ (for $5 \mathrm{~s}$ ). Then the nozzle with filters was raised and held in the upright position for $10 \mathrm{~s}$. After this procedure, a nozzle with filters was placed above the pyrosequencing plate (without touching the primer solution with the nozzle filters), the vacuum was turned off and only after that the nozzle filters were lowered into the plate. In 2 min the nozzle with filters was removed from the pyrosequencing plate. The pyrosequencing plate was placed on a thermostat at $80^{\circ} \mathrm{C}$ for $2 \mathrm{~min}$. Before placing the plate into the sequencer, it was given time to cool down. During the cooling of the plate, the reagents $E$ (enzyme) and $S$ (substrate) were diluted with $\mu \mathrm{Q} \mathrm{H}_{2} \mathrm{O}, \mathrm{E}, \mathrm{S}$, and individual dNTPs were poured into the cuvette, according to the instructions, at the amount indicated for setting the mode for sequencing. After that, the cuvette with the reagents and the samples was put into the sequencer and the program was launched.

The sequences of primers for pyrosequence were given in the article of Sazonova et al. ${ }^{[16]}$ Visualization of the results was carried out with the use of a computer program, which was completed with the pyrosequenator. The heteroplasmy level of every mitochondrial genome mutation was assessed on the basis of the pyrogram of a DNA sample from each study participant, using a formula previously developed by Sazonova et al. ${ }^{[16,17]}$ with colleagues: $P=(\mathrm{h}-\mathrm{N}) /(\mathrm{M}-\mathrm{N})$ $\times 100$, where " $P$ " is the heteroplasmy percentage of the studied mutations; " $h$ " is the height of the peak of the investigated nucleotide; "N" is the height of the peak 
of the investigated nucleotide corresponding to the presence of $100 \%$ normal copies of the mitochondrial genome in the sample; "M" is the height of the peak of the investigated nucleotide corresponding to the presence of $100 \%$ mutant copies of the mitochondrial genome in the sample.

It should be emphasized that, alongside the genetic screening, a number of biochemical indicators was investigated in blood of the study participants: total cholesterol, triglycerides blood sugar level, low and high density lipoproteins ${ }^{[20,21]}$.

\section{RESULTS}

At the first stage of the study, demographic characteristics of 700 study participants were obtained [Table 1]. The data in this table are presented by means of an average value with the standard deviation (in parentheses).

In the group of conventionally healthy participants, women predominated, while in the group of patients with pre-clinical atherosclerosis, men predominated [Table 1]. Patients with pre-clinical atherosclerosis were characterized by a significantly older age, and also by higher levels of total cholesterol and lowdensity lipoproteins cholesterol in men $(P \leq 0.01)$. This group showed a tendency to an increase in the frequency of smoking $(P \leq 0.1)$. In terms of body mass index, blood pressure and triglyceride levels, there were no significant differences between the studied groups.

At the second stage of the study the threshold heteroplasmy level of 11 investigated mutations (m.5178C>A, m.15059G >A, m.652delG, m.13513G >A, m.14846G >A, m.652insG, m.12315G $>A, m .3336 \mathrm{~T}>\mathrm{C}$, $\mathrm{m} .1555 \mathrm{~A}>\mathrm{G}, \quad \mathrm{m} .14459 \mathrm{G}>\mathrm{A}$ and $\mathrm{m} .3256 \mathrm{C}>\mathrm{T}$ ) in individuals with atherosclerotic plaques or an increased IMT CA was detected. It should be noted that the percentage of mitochondrial genome copies with higher than the threshold level was associated with the occurrence and development of atherosclerotic lesions in patients. At the same time, achieving and exceeding the threshold heteroplasmy level of antiatherogenic mutations is thought to have the effect of lowering incidence of this disease.

The evaluation results of the threshold heteroplasmy level of mutations in atherosclerotic plaques and an increased IMT CA of the carotid arteries of the study participants are shown in Table 2.

The selection of the optimal threshold heteroplasmy level for each investigated mutation was detected using ROC-curve analysis. It was based on simultaneous maximizing of the sensitivity values (Y-axis) and minimizing the value (1-specificity) (X-axis). The example of such a ROC-curve analysis of a mutation m.12315G $>A$ connection with the occurrence of atherosclerotic plaques in carotid arteries is shown [Figure 1 and Table 3].

Therefore, the threshold heteroplasmy level for mitochondrial genome mutation m.12315G $>A$ was found to be a rather strong predictor of the atherosclerotic plaques occurrence in carotid arteries. The area of a ROC-curve for this mutation was found to be 0.577 . The optimal threshold value of heteroplasmy level for m.12315G>A was $10.5 \%$ (sensitivity was 0.6 ; specificity was 0.53 ).

As can be seen from the Table 2, the levels of heteroplasmy of investigated mitochondrial mutations in a sample of patients with atherosclerotic plaques and in a sample of patients with an increased IMT CA are approximately the same.

Table 1: Demographic characteristics of the study participants

\begin{tabular}{lccc}
\hline Value & $\begin{array}{c}\text { Conventionally healthy } \\
\text { study participants }\end{array}$ & $\begin{array}{c}\text { Patients with preclinical } \\
\text { atherosclerosis }\end{array}$ & Significance \\
\hline Systolic blood pressure (mmHg) & $129(15.7)$ & $141(14.1)$ & 0.26 \\
Body-weight index (kg/sq.m) & $25.6(7.3)$ & $29.3(6.4)$ & 0.45 \\
Male:female (number of persons) & $159: 180$ & $203: 158$ & $0.002^{* *}$ \\
Smoking (\%) & $20(10.6)$ & $42(9.5)$ & $0.10^{*}$ \\
Cholesterol LDL (mmol/L) & $4.03(1.07)$ & $4.38(1.09)$ & $0.001^{* *}$ \\
Diastolic blood pressure (mmHg) & $78(16.7)$ & $89(17.3)$ & 0.38 \\
Age (years) & $53(8.5)$ & $64(8.9)$ & $0.003^{* *}$ \\
Total cholesterol (mmol/L) & $6.39(1.21)$ & $6.76(1.09)$ & $0.001^{* *}$ \\
Triglycerides (mmol/L) & $1.48(0.61)$ & $1.51(0.64)$ & 0.290 \\
Cholesterol HDL (mmol/L) & $1.70(0.48)$ & $1.53(0.52)$ & $0.002^{* *}$ \\
\hline
\end{tabular}

*: the differences between conventionally healthy study participants and patients with atherosclerosis are at the significance level $P$ $\leq 0.1 ;{ }^{* *}$ : significant differences between conventionally healthy study participants and patients with atherosclerosis; LDL: low-density lipoproteins; HDL: high-density lipoproteins 
Table 2: The threshold value of heteroplasmy level of mtDNA mutations associated with atherosclerosis

\begin{tabular}{lccc}
\hline Gene & Mutation & $\begin{array}{c}\text { Threshold value } \\
\text { of heteroplasmy } \\
\text { level in } \\
\text { atherosclerotic } \\
\text { plaques (\%) }\end{array}$ & $\begin{array}{c}\text { Threshold } \\
\text { value of } \\
\text { heteroplasmy } \\
\text { level in } \\
\text { thickened } \\
\text { IML CA (\%) }\end{array}$ \\
\hline MT-TL1 & m.3256C $>$ T & 15.5 & 16.5 \\
MT-RNR1 & m.652delG & 20.5 & 21.5 \\
MT-CYTB & m.14846G $>\mathrm{A}^{*}$ & 17.5 & 17.5 \\
MT-TL2 & m.12315G $>\mathrm{A}$ & 7.5 & 10.5 \\
MT-ND1 & $\mathrm{m} .3336 \mathrm{~T}>\mathrm{C}$ & 6.5 & 7.5 \\
MT-RNR1 & $\mathrm{m} .652 \mathrm{insG}$ & 20.0 & 20.0 \\
MT-CYTB & $\mathrm{m} .15059 \mathrm{G}>\mathrm{A}$ & 24.5 & 26.5 \\
MT-RNR1 & $\mathrm{m} .1555 \mathrm{~A}>\mathrm{G}$ & 17.5 & 19.5 \\
MT-ND5 & $\mathrm{m} .13513 \mathrm{G}>\mathrm{A}^{*}$ & 32.5 & 33.5 \\
MT-ND2 & $\mathrm{m} .5178 \mathrm{C}>\mathrm{A}$ & 6.5 & 6.5 \\
MT-ND6 & $\mathrm{m} .14459 \mathrm{G}>\mathrm{A}$ & 4.5 & 4.5 \\
\hline
\end{tabular}

*: antiatherosclerotic mutations; IML CA: intima-medial layer of carotid arteries

Table 3: Detection of the optimal threshold heteroplasmy level value for $\mathrm{m} .12315 \mathrm{G}>\mathrm{A}$ on the basis of $\mathrm{ROC}$-analysis

\begin{tabular}{lcc}
\hline \multicolumn{3}{c}{ Coordinates of the curve } \\
Threshold & Sensitivity & $\mathbf{1}$ - Specificity \\
heteroplasmy level & 0.825 & 0.795 \\
4.50 & 0.789 & 0.667 \\
5.50 & 0.719 & 0.643 \\
6.50 & 0.684 & 0.608 \\
7.50 & 0.632 & 0.544 \\
8.50 & 0.614 & 0.485 \\
9.50 & 0.596 & 0.468 \\
$10.50^{*}$ & 0.579 & 0.468 \\
11.50 & 0.561 & 0.433 \\
12.50 & 0.544 & 0.415 \\
13.50 & 0.544 & 0.398 \\
14.50 & 0.526 & 0.363 \\
16.00 & 0.474 & 0.339 \\
17.50 & 0.421 & 0.310 \\
18.50 & 0.404 & 0.287 \\
19.50 & 0.386 & 0.269 \\
20.50 & 0.386 & 0.246 \\
21.50 & 0.351 & 0.24 \\
22.50 & 0.333 & 0.228 \\
23.50 & 0.333 & 0.216 \\
24.50 & 0.316 & 0.193 \\
25.50 & 0.298 & 0.187 \\
26.50 & 0.298 & 0.181 \\
27.50 & &
\end{tabular}

ROC: receiver operating characteristic

It is necessary to mention that during the analysis of all the 11 investigated mutations in patients, it was possible to explain more than $84 \%$ of cases of atherosclerotic plaques occurrence and thickening of intima-medial layer of carotid arteries.

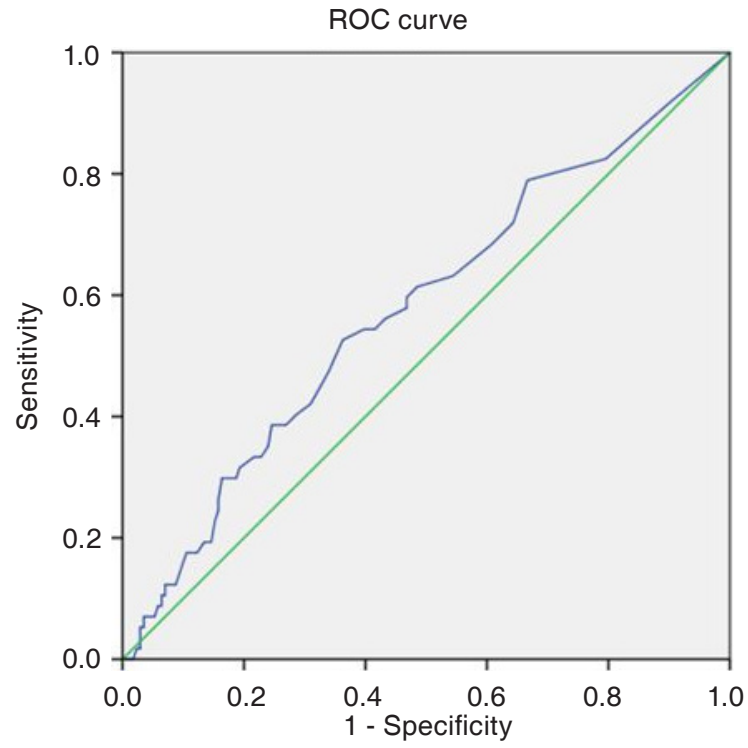

Figure 1: ROC-curve for the analysis of the link of the heteroplasmy level in mitochondrial genome mutation m.12315G $>A$ with the occurrence of atherosclerotic plaques in carotid arteries: area under the curve 0.577 (standard error 0.015); $P \leq 0.042$. ROC: receiver operating characteristic

\section{DISCUSSION}

Atherosclerosis of human major vessels is often a cause of mortality from cardiovascular diseases. In this pathology, the intima of arteries is damaged, luminal occlusion occurs and blood supply to organs deteriorates ${ }^{[1-5]}$. Atherosclerosis is difficult to recognize in the early stages. Molecular genetic markers could help the diagnostics of this disease. Unfortunately, compared to traditional single risk factors of atherosclerosis, nuclear genome mutations have rather low diagnostic and prognostic significance.

According to the literature, a variety of diseases is associated with some mutations in mtDNA. These mutations often correlate with pathologies which often occur together with atherosclerosis ${ }^{[11-15]}$. The penetrance of mtDNA mutations depends on the percentage of normal and mutant copies of genome, i.e. the heteroplasmy level of mitochondrial mutations. That is why, during the analysis of the linkage of mitochondrial genome mutations with human diseases, the value of heteroplasmy level above which a person begins the occurrence and development of pathologies or begins to show a protective effect of mutations needs to be determined. The information about the threshold heteroplasmy level of mitochondrial genome mutations, associated with certain diseases, can help in assessing the predisposition and the early diagnosis of these pathologies. 
As a working hypothesis for the present study, we used the monoclonal hypothesis according to which, if a mutation occurs in the mitochondrial genome, the ATP synthesis is disturbed. The cells containing mitochondria with mutant mtDNA begin to suffer a shortage of energy and proliferate unlimitedly. The number of defective mitochondrial genome copies becomes greatly increased. Finally a mutation reaches the threshold heteroplasmy level and the pathological process starts. This results in the occurrence and development of atherosclerotic lesions. When the threshold heteroplasmy level is reached by antiatherogenic mutations, they begin to show a protective effect. That is why, in people with a high heteroplasmy level for antiatherogenic mutations, atherosclerosis is absent.

For heteroplasmy level evaluation of investigated samples, a new original method of quantitative assessment of mutant allele in mitochondrial genome, based on pyrosequencing technology, was developed by the author and her colleagues ${ }^{[16]}$. With the use of this method, it is possible to measure the heteroplasmy level of both hereditary and somatic mitochondrial genome mutations, occurring during the lifetime of an individual or in pathologic processes. The method of quantitative assessment of the mutant allele of mitochondrial genome has a number of significant advantages compared to other quantitative methods such as invasive cleavage of the oligonucleotide probe (Invader), high-performance liquid chromatography, heteroduplex analysis, the analysis of heteroplasmy using Surveyor nuclease, ARMS, SNaPshot, HRM, TGGE, Sanger sequencing, NGS using 454/Roche equipment, Applied Biosystems SOLiD, Illumina equipment series used for the analysis of mutations ${ }^{[35-39]}$.

Pyrosequencing has the smallest number of defects and the greatest number of advantages, compared to other methods of measuring the percentage of heteroplasmy of mitochondrial genome ${ }^{[40-44]}$. It provides a unique opportunity to analyze a very short DNA fragment containing the region of the investigated mutation. The size of such a DNA fragment is, on average, 5-10 bp, it significantly reduces the probability of mistakes made during the analysis. As a result, the method developed by the author with colleagues, based on pyrosequencing technology, can serve as the "gold standard" for all other methods of determining the percentage of mitochondrial genome heteroplasmy and it should be used to verify the heteroplasmy level of mutations detected by other methods.

With the aim of subsequent molecular genetic diagnosis of atherosclerosis in blood cells of the study participants, the threshold value of the heteroplasmic percentage for each mutation was detected, after which the occurrence and development of atherosclerotic lesions begins in an individual, and for anti-atherogenic mutations, an antipathological effect begins to manifest. It should be emphasized that the choice of the optimal threshold value was based on simultaneous maximization of sensitivity and specificity. The revealed good agreement of the threshold heteroplasmy percentage value in the 11 mitochondrial genome mutations for atherosclerotic plaques and the thickening of the carotid intimal-medial layer can be indicative of general pathophysiological mechanisms of the formation of lesions in intimal carotid arteries.

The investigated mutations are localized in the coding region of mitochondrial genome. Let's consider each of them.

Mutation m.652delG was localized in the MTRNR1 gene. It causes a structural defect of the 12S rRNA subunit, which can lead to a partial or complete dysfunction of the mitochondrial ribosome.

A consequence of this mutation may be a decrease in synthesis of protein subunits of the enzymes of the mitochondrial respiratory chain. As a result, the synthesis of ATP may decrease, leading to an energy failure in the mitochondria and intimal cells of arteries. It can, as a compensatory mechanism, lead to unlimited proliferation of mitochondria and cells. The result of this process can be the occurrence of atherosclerotic plaques and thickening of the intima-medial layer of human arteries.

Probably, mutation m.652insG (MT-RNR1 gene) associated with the absence of atherosclerosis stabilizes subunit $12 S$ of rRNA and improves the functions of ribosomes. Perhaps, in case of occurrence of this insertion, the synthesis of protein chains in enzymes of mitochondrial respiratory chains increases. It leads to an increase in the synthesis of ATP and protects mitochondria and cells from oxidative stress. Therefore, this mutation can perform protective functions.

Mitochondrial genome mutation m.1555A $>\mathrm{G}$ is also encoded by MT-RNR1 gene.The mutation has an antiatherogenic effect. It also leads by far the most to the stabilization of the mitochondrial ribosome.

In case of a single-nucleotide substitution of m.3256C>T (MT-TL1 gene), transport RNA-Leucine dysfunction (recognition codon UUR) can occur. If leucine is the last in the protein subunit of the enzyme, then without this tRNA, the protein cannot be separated from the ribosome. It can lead to a dysfunction of 
some ribosomes in mitochondria and to a decrease in synthesis of respiratory chain enzymes.

Single nucleotide substitution m.3336T>C (MT-ND1 gene) is a silent mutation. In case of its occurrence, there is no replacement of the amino acid in the first protein subunit of NADH dehydrogenase. Meanwhile, the mutation is associated with atherosclerotic lesions. Probably, this mutation is linked to an atherogenic haplotype.

Mutation m.5178C>A (MT-ND2 gene) results in the replacement of an amino acid (Leu>Met). Although in some earlier literary sources ${ }^{[45]}$ it is reported that $\mathrm{m} .5178 \mathrm{C}>\mathrm{A}$ is anti-atherogenic, in this study, in a sample of 700 study participants, the association of this mutation with atherosclerotic lesions was found. Probably in earlier studies, an undersampling has played a role.

The single nucleotide replacement of guanine by adenine at the position of the mitochondrial genome 12315 results in a change in the tertiary structure of the transport RNA-Leu (recognition codon CUN). It can lead to a dysfunction of this tRNA, leading to a decrease in synthesis of the protein chains in respiratory chain enzymes, which contain amino acid leucine.

Mutation m.13513G $>$ A leads to the replacement of the amino acid (Asp>Asn) in the 5th protein subunit of the respiratory chain enzyme NADH-dehydrogenase. Perhaps, as a result of this mutation, the efficiency of complex 1 of the respiratory chain, leading to an increase in the production of energy in the cell, is improved. Our research team discovered the antiatherogenic effect of this mutation.

Mutation m.14459G>A (MT-ND6 gene) results in amino acid substitution (Ala>Val) at position 72 of the 6 th protein subunit of NADH dehydrogenase. Probably, this mutation causes a defect in the enzyme, leading to the appearance of atherosclerotic lesions.

The single nucleotide substitution m.14846G>A (MTCYTB gene) results in the amino acid substitution (Gly>Ser) of cytochrome B. Probably, this mutation stabilizes the complex of the III respiratory chain, into which this cytochrome is included. The result of this mutation may be an increase in the synthesis of ATP in the cell. It can protect cells and tissues from the occurrence of atherosclerosis.

Mutation m.15059G $>\mathrm{A}$, localized in the MT-CYTB gene, leads to a formation of a stop codon. This stops the synthesis of cytochrome B, which becomes 244 amino acids shorter. Perhaps, this mutation leads to the dysfunction of complex III of the respiratory chain. As a result of this process, atherosclerotic lesions can develop in the cells and arteries in general.

It is necessary to note the novelty and uniqueness of this study. According to the analysis of literary sources, there is not any scientific article in the world where the threshold heteroplasmy level of mitochondrial genome mutations and their association with predisposition to atherosclerosis has been studied. In addition, there are not any similar works for other human diseases either.

Information about the threshold heteroplasmy level in mitochondrial genome mutations, associated with atherosclerosis and its risk factors, can help in assessing the predisposition and the early diagnostics of these pathologies. The obtained data can be used to create test systems for atherosclerosis diagnostics.

In conclusion, the article dedicated to detection of a threshold heteroplasmy level of mitochondrial genome mutations in patients with atherosclerotic lesions in blood vessels, is quite relevant and well-timed. This work is characterized by a high degree of novelty, because similar works in world literature are absent. Using the method, developed in our laboratory ${ }^{[16,17]}$, we managed to determine threshold heteroplasmy levels of 11 mitochondrial genome mutations associated with atherosclerosis. We suppose that threshold heteroplasmy levels of these mutations is a new criterion for evaluation of predisposition to the occurrence and development of atherosclerotic lesions in human arteries.

\section{DECLARATIONS}

\section{Authors' contributions}

Study design: M.A. Sazonova

Data collection: M.A. Sazonova, E.V. Galitsyna, V.A. Orekhova

Experimental studies: M.A. Sazonova, A.I. Ryzhkova, V.V. Sinyov

Literature search: A.A. Melnichenko

Statistical analysis: I.A. Sobenin

Manuscript writing, preparation and editing: M.A. Sazonova

Manuscript review: A.N. Orekhov, A.L. Ravani

\section{Financial support and sponsorship}

This work was supported by the Russian Scientific Foundation (Grant \#14-14-01038). 


\section{Conflicts of interest}

There are no conflicts of interest.

\section{Patient consent}

All the study participants gave an informed consent in written form.

\section{Ethics approval}

It was endorsed by the local ethics committees of the Institute for Atherosclerosis Skolkovo Innovation Center, Moscow, Russia and Research, Institute of General Pathology and Pathophysiology, Moscow, previous to their inclusion in the study.

\section{REFERENCES}

1. Saho T, Onishi H. Evaluation of the impact of carotid artery bifurcation angle on hemodynamics by use of computational fluid dynamics: a simulation and volunteer study. Radiol Phys Technol 2016;9:277-85.

2. Orekhov AN, Melnichenko AA, Sobenin IA. Approach to reduction of blood atherogenicity. Oxid Med Cell Longev 2014;2014:738679.

3. Nus M, Mallat Z. Immune-mediated mechanisms of atherosclerosis and implications for the clinic. Expert Rev Clin Immunol 2016;12:1217-37.

4. Sobenin IA, Galitsyna EV, Grechko AV, Orekhov AN. Small dense and desialylated low density lipoprotein in diabetic patients. Vessel Plus 2017;1:29-37.

5. Wu GC, Leng RX, Lu Q, Fan YG, Wang DG, Ye DQ. Subclinical atherosclerosis in patients with inflammatory Bowel diseases: a systematic review and meta-analysis. Angiology 2017;68:447-61.

6. Maruthur NM, Li M, Halushka MK, Astor BC, Pankow JS, Boerwinkle E, Coresh J, Selvin E, Kao WH. Genetics of plasma soluble receptor for advanced glycation end-products and cardiovascular outcomes in a community-based population: results from the atherosclerosis risk in communities study. PLoS One 2015;10:e128452.

7. Dai X, Wiernek S, Evans JP, Runge MS. Genetics of coronary artery disease and myocardial infarction. World J Cardiol 2016;8:1-23.

8. Pokharel Y, Sun W, Polfus LM, Folsom AR, Heiss G, Sharrett AR, Boerwinkle E, Ballantyne CM, Hoogeveen RC. Lipoprotein associated phospholipase A2 activity, apolipoprotein C3 loss-offunction variants and cardiovascular disease: the Atherosclerosis Risk In Communities Study. Atherosclerosis 2015;241:641-8.

9. Yu B, Li AH, Muzny D, Veeraraghavan N, de Vries PS, Bis JC, Musani SK, Alexander D, Morrison AC, Franco OH, Uitterlinden A, Hofman A, Dehghan A, Wilson JG, Psaty BM, Gibbs R, Wei P, Boerwinkle E. Association of rare loss-of-function alleles in HAL, serum histidine: levels and incident coronary heart disease. Circ Cardiovasc Genet 2015;8:351-5.

10. Inanloorahatloo K, Zand Parsa AF, Huse K, Rasooli P, Davaran S, Platzer M, Fan JB, Amini S, Steemers F, Elahi E. Mutation in CYP27A1 identified in family with coronary artery disease. Eur $J$ Med Genet 2013;56:655-60.

11. Han CB, Ma JM, Xin Y, Mao XY, Zhao YJ, Wu DY, Zhang SM, Zhang YK. Mutations of mitochondrial 12S rRNA in gastric carcinoma and their significance. World J Gastroenterol 2005;11:31-5.

12. Zhelankin A, Khasanova Z, Barinova L, Sazonova M, Postnov A, Sobenin I. 1A.06: mitochondrial DNA haplogroup H is associated with subclinical carotid atherosclerosis in russian population. $J$ Hypertens 2015;33:e2.

13. Solano A, Roig M, Vives-Bauza C, Hernandez-Peña J, Garcia-Arumi E, Playan A, Lopez-Perez MJ, Andreu AL, Montoya J. Bilateral striatal necrosis associated with a novel mutation in the mitochondrial ND6 gene. Ann Neurol 2003;54:527-30.

14. Jeppesen TD, Schwartz M, Hansen K, Danielsen ER, Wibrand F, Vissing J. Late onset of stroke-like episode associated with a 3256C-$>$ T point mutation of mitochondrial DNA. J Neurol Sci 2003;214:1720.

15. Horváth R, Scharfe C, Hoeltzenbein M, Do BH, Schröder C, Warzok R, Vogelgesang S, Lochmüller H, Müller-Höcker J, Gerbitz KD, Oefner PJ, Jaksch M. Childhood onset mitochondrial myopathy and lactic acidosis caused by a stop mutation in the mitochondrial cytochrome c oxidase III gene. J Med Genet 2002;39:812-6.

16. Sazonova M, Budnikov E, Khasanova Z, Sobenin I, Postnov A, Orekhov A. Studies of the human aortic intima by a direct quantitative assay of mutant alleles in the mitochondrial genome. Atherosclerosis 2009;204:184-90.

17. Sazonova MA, Sinyov VV, Barinova VA, Ryzhkova AI, Zhelankin AV, Postnov AY, Sobenin IA, Bobryshev YV, Orekhov AN. Mosaicism of mitochondrial genetic variation in atherosclerotic lesions of the human aorta. Biomed Res Int 2015;2015:825468.

18. Sazonova MA, Chicheva MM, Zhelankin AV, Sobenin IA, Bobryshev $\mathrm{YV}$, Orekhov AN. Association of mutations in the mitochondrial genome with the subclinical carotid atherosclerosis in women. Exp Mol Pathol 2015;99:25-32.

19. Sobenin IA, Sazonova MA, Ivanova MM, Zhelankin AV, Myasoedova VA, Postnov AY, Nurbaev SD, Bobryshev YV, Orekhov AN. Mutation C3256T of mitochondrial genome in white blood cells: novel genetic marker of atherosclerosis and coronary heart disease. PLoS One 2012; 7:e46573.

20. Sobenin IA, Surnin SA, Karagodin VP, Miasoedova VA, Kirichenko TV, Chuprakova OV, Kozhevnikova IuA, Kovalevskaia LO, Orekhov AN. Variability of intima-media thickness of the common carotid arteries in Moscow city population without clinical symptoms of atherosclerosis. Ter Arkh 2011;83:58-62. (in Russian)

21. Sobenin IA, Myasoedova VA, Anisimova EV, Pavlova XN, Möhlenkamp S, Schmermund A, Seibel R, Berenbein S, Lehmann N, Moebus S, Jöckel K, Orekhov AN, Erbel R. Blood serum atherogenicity and coronary artery calcification. Curr Pharm Des 2014;20:5884-8

22. Myasoedova VA, Kirichenko TV, Melnichenko AA, Orekhova VA, Ravani A, Poggio P, Sobenin IA, Bobryshev YV, Orekhov AN. Antiatherosclerotic effects of a phytoestrogen-rich herbal preparation in postmenopausal women. Int J Mol Sci 2016;17:E1318.

23. Kirichenko TV, Myasoedova VA, Orekhova VA, Ravani AL, Nikitina NA, Grechko AV, Sobenin IA, Orekhov AN. Phytoestrogenrich natural preparation for treatment of climacteric syndrome and atherosclerosis prevention in perimenopausal women. Phytother Res 2017;31:1209-14.

24. Aguilera I, Dratva J, Caviezel S, Burdet L, de Groot E, Ducret-Stich RE, Eeftens M, Keidel D, Meier R, Perez L, Rothe T, Schaffner E, Schmit-Trucksäss A, Tsai MY, Schindler C, Künzli N, Probst-Hensch N. Particulate matter and subclinical atherosclerosis: associations between different particle sizes and sources with carotid intimamedia thickness in the SAPALDIA study. Environ Health Perspect 2016;124:1700-06.

25. Liu X, Lian H, Ruan Y, Liang R, Zhao X, Routledge M, Fan Z. Association of exposure to particular matter and carotid intima-media thickness: a systematic review and meta-analysis. Int J Environ Res Public Health 2015;12:12924-40.

26. Touboul PJ, Hennerici MG, Meairs S, Adams H, Amarenco P, Bornstein N, Csiba L, Desvarieux M, Ebrahim S, Hernandez Hernandez R, Jaff M, Kownator S, Naqvi T, Prati P, Rundek T, Sitzer M, Schminke U, Tardif JC, Taylor A, Vicaut E, Woo KS. Mannheim carotid intimamedia thickness and plaque consensus (2004-2006-2011). An update 
on behalf of the advisory board of the 3rd, 4th and 5th watching the risk symposia, at the 13th, 15th and 20th European Stroke Conferences, Mannheim, Germany, 2004, Brussels, Belgium, 2006, and Hamburg, Germany, 2011. Cerebrovasc Dis 2012;34:290-6.

27. Amato M, Veglia F, de Faire U, Giral P, Rauramaa R, Smit AJ, Kurl S, Ravani A, Frigerio B, Sansaro D, Bonomi A, Tedesco CC, Castelnuovo S, Mannarino E, Humphries SE, Hamsten A, Tremoli E, Baldassarre D; IMPROVE study group. Carotid plaque-thickness and common carotid IMT show additive value in cardiovascular risk prediction and reclassification. Atherosclerosis 2017;263:412-9.

28. Sobenin IA, Zhelankin AV, Mitrofanov KY, Sinyov VV, Sazonova MA, Postnov AY, Orekhov AN. Mutations of mitochondrial DNA in atherosclerosis and atherosclerosis-related diseases. Curr Pharm Des 2015;21:1158-63.

29. Maniatis T, Fritsch EF, Sambrook J. Molecular cloning : a laboratory manual. Cold Spring Harbor: Cold Spring Harbor Laboratory; 1982.

30. Zhang XX, Li MR, Cao Y, Zhang RW, Zhang Y, Li F, Xi HL, Xu XY. Dynamics of genotypic mutations of the hepatitis $\mathrm{B}$ virus associated with long-term entecavir treatment determined with ultradeep pyrosequencing: a retrospective observational study. Medicine (Baltimore) 2016;95:e2614

31. Harrington CT, Lin EI, Olson MT, Eshleman JR. Fundamentals of pyrosequencing. Arch Pathol Lab Med 2013;137:1296-303.

32. Kreutz M, Schock G, Kaiser J, Hochstein N, Peist R. PyroMark ${ }^{\circledR}$ instruments, chemistry, and software for Pyrosequencing ${ }^{\circledR}$ analysis. Methods Mol Biol 2015;1315:17-27.

33. Rajatileka S, Luyt K, Williams M, Harding D, Odd D, Molnár E, Váradi A. Detection of three closely located single nucleotide polymorphisms in the EAAT2 promoter: comparison of single-strand conformational polymorphism (SSCP), pyrosequencing and Sanger sequencing. BMC Genet 2014;15:80.

34. Simou M, Kouskouni E, Vitoratos N, Economou E, Creatsas G. Polymorphisms of platelet glycoprotein receptors and cell adhesion molecules in fetuses with fetal growth restriction and their mothers as detected with pyrosequencing. In Vivo 2017;31:243-9.

35. Mahmood U, Imran M, Naik SI, Cheema HA, Saeed A, Arshad M, Mahmood S. Detection of common mutations in the GALT gene through ARMS. Gene 2012;509:291-4.
36. Fondevila M, Børsting C, Phillips C, de la Puente M, Consortium EN, Carracedo A, Morling N, Lareu MV. Forensic SNP genotyping with SNaPshot: technical considerations for the development and optimization of multiplexed SNP assays. Forensic Sci Rev 2017;29:5776.

37. Salimullah M, Hamano $K$, Tachibana $M$, Inoue $K$, Nishigaki $K$ Efficient SNP analysis enabled by joint application of the muTGGE and heteroduplex methods. Cell Mol Biol Lett 2005;10:237-45.

38. Sazonova MA, Shkurat TP, Demakova NA, Zhelankin AV, Barinova VA, Sobenin IA, Orekhov AN. Mitochondrial genome sequencing in atherosclerosis: what's next? Curr Pharm Des 2016;22:390-6.

39. Ladouceur M, Zheng HF, Greenwood CM, Richards JB. Empirica power of very rare variants for common traits and disease: results from sanger sequencing 1998 individuals. Eur J Hum Genet 2013;21:102730.

40. Georghiou SB, Seifert M, Lin SY, Catanzaro D, Garfein RS, Jackson RL, Crudu V, Rodrigues C, Victor TC, Catanzaro A, Rodwell TC. Shedding light on the performance of a pyrosequencing assay for drug-resistant tuberculosis diagnosis. BMC Infect Dis 2016;16:458.

41. Yeo MK, Jung MK, Lee SY, Lee YM, Hur GM, Kim JM. The usefulness of a novel fully automated PCR-based Idylla test for detection of the BRAF V600E mutation in thyroid tissue: comparison with PNA-clamping PCR, real-time PCR and pyrosequencing. J Clin Pathol 2017;70:260-5

42. Mohamed S, Bourliere M, Benali S, Oules V, Castellani P, Khiri H, Camus C, Penaranda G, Chiche L, Gonzalez D, Sayada C, Olive D, Halfon P. Clinical relevance of the HCV protease inhibitor-resistant mutant viral load assessed by ultra-deep pyrosequencing in treatment failure. J Clin Virol 2016;78:36-43.

43. Pu D, Mao C, Cui L, Shi Z, Xiao P. Pyrosequencing with di-base addition for single nucleotide polymorphism genotyping. Anal Bioanal Chem 2016;408:3113-23.

44. Kuscu C, Kuscu C. Pyrosequencing analysis for breast cancer DNA methylome. Methods Mol Biol 2016;1406:89-104.

45. Matsunaga H, Tanaka Y, Tanaka M, Gong JS, Zhang J, Nomiyama T, Ogawa O, Ogihara T, Yamada Y, Yagi K, Kawamori R. Antiatherogenic mitochondrial genotype in patients with type 2 diabetes. Diabetes Care 2001;24:500-3. 